(๑) Entomologica Fennica. 3.XII.1992

\title{
The arthropod complex associated with Ips typographus (L.) (Coleoptera, Scolytidae): species composition, phenology, and impact on bark beetle productivity
}

\author{
Jan Weslien
}

\begin{abstract}
Weslien, J. 1992: The arthropod complex associated with Ips typographus (L.) (Coleoptera, Scolytidae): species composition, phenology, and impact on bark beetle productivity. — Entomol. Fennica 3:205-213.

The biology of forest arthropods associated with the bark beetle Ips typographus and the impact of these associates on bark beetle productivity were investigated in the field. Arthropods were allowed access to spruce bolts for different lengths of time, $0,1,4$, and 8 weeks, following onset of attack by Ips typographus, after which time the bolts were moved to a nonforested area and caged. Arthropods were collected as they emerged from the bolts in autumn and the following spring. At least 32 arthropod species were collected, of which 17 are known to feed on bark beetle brood. The longer the exposure period the more bark beetle enemies and the fewer Ips typographus emerged. Natural enemies were estimated to have reduced bark beetle productivity by 83\%. Arrival and emergence patterns and relative impact on bark beetle productivity of different species are discussed.
\end{abstract}

Jan Weslien, Swedish University of Agricultural Sciences, Division of Forest Entomology, P.O. Box 7044, S-75007 Uppsala

\section{Introduction}

Most species of bark beetles (Scolytidae) breed under the bark of woody plants. The bark offers protection from many generalist predators, but a great number of predators and parasites are specialists that can attack the subcortical life stages (see e.g. Dahlsten 1981, Mills 1983, Moeck \& Safranyik 1984).

Field studies have shown that natural enemies can reduce bark beetle emergence significantly (Moore 1972, Linit \& Stephen 1983, Miller 1984, 1986, Riley \& Goyer 1986). All of these studies were made in the southeastern part of North America. This region has a warm climate, and the bark beetles have several generations per year, which may favour the build-up of predator and parasite populations. Few quantative studies on the impact of natural enemies on bark beetle productivity have been done in temperate regions with univoltine bark beetles (see Scandinavian studies referred to below).

The spruce bark beetle Ips typographus (L.) is one of the most injurious insects attacking Norway spruce, Picea abies L. (Karsten) in Eurasia. The biology of this bark beetle has been intensively studied, and the arthropod complex associated with it is well known. About 140 arthropod species mainly from the orders Coleoptera, Diptera, Hymenoptera, and Acarida, have been 
documented to occur in Ips typographus galleries in Europe. Many of these species are saprophagous or have unclear feeding habits but at least 60 of them have been reported to feed on the immature stages of bark beetles (Saalas 1917, Sachtleben 1952, Hedqvist 1963, Nuorteva 1956, 1957, 1958, Klausnitzer \& Förster 1974, Merlin et al. 1986, Moser \& Bogenschütz 1984, Moser et al. 1989, Ounap 1980, 1986).

Field experiments in Scandinavia indicated that mechanical exclusion of natural enemies from stems attacked attacked by Ips typographus led to an increase in bark beetle productivity (Pettersen \& Tvermyr 1971, Weslien \& Regnander 1992). However, in these studies the exclusion was not total, and all insects involved were not thoroughly counted and determined to species.

The phenology of many insect species associated with Ips typographus in Fennoscandia is not well known. This is true for the time of arrival at attacked trees as well as for the time for emergence from these trees.

The aim of the present study was to estimate the impact of predation and parasitism under bark on the productivity of Ips typographus. It was of high priority to determine the density and the arrival and emergence times of the different species involved.

\section{Materials and methods}

The study site was located $15 \mathrm{~km}$ north of Uppsala in central Sweden. Along a forest edge bordering a 5-year-old clear-felling, spruce bark beetle attacks had occurred on windthrown and standing spruce trees for at least three years prior to the study (1983-1985). It was therefore assumed that a build-up of natural enemy populations had occurred in the area. Bark samples taken in November 1985 confirmed that larvae of Diptera and Hymenoptera were abundant. In 1985 two standing trees and four fallen trees had been colonized by Ips typographus.

In early spring 1986 , two spruce trees were felled, and 12 bolts (length 65-70 cm, diameter $16-22 \mathrm{~cm}$, mean bark area $0.35 \mathrm{~m}^{2}$ ) were cut from each tree. The ends of the bolts were sealed with paraffin to prevent severe desiccation.

The experiment had a randomized block design with six blocks and four treatments. Each block consisted of four neighbouring bolts (i.e. a stem section cut in four pieces). Insects were allowed access to the bolts for different lengths of time following attack by Ips typographus. The treatments were:

OW = no exposure; bark beetles were released on the bolts in cages.

$1 \mathrm{~W}=$ exposure for 1 week after the first observed Ips typographus attacks.

$4 \mathrm{~W}=$ exposure for 4 weeks after the first observed Ips typographus attacks.

$8 \mathrm{~W}=$ exposure for 8 weeks after the first observed Ips typographus attacks.

Exposure was discontinued by putting the bolts in screen cages $(83 \times 44 \times 44 \mathrm{~cm}, 1 \mathrm{~mm}$ screening), that were held in a nonforested area (in Uppsala). The bolts were moved to this area with low populations of forest insects, since small parasitoids and predators might otherwise have entered through the screen.

Bolts in the $0 \mathrm{~W}$ treatment were stored in Uppsala throughout the experiment. Spruce bark beetles were captured in pheromone traps about $2 \mathrm{~km}$ from the experimental site, and 300-400 specimens were released in each cage on 6 June. Thereafter the $0 \mathrm{~W}$ bolts were held in a greenhouse for 10 days after which time they were moved outside to a shaded place where caged bolts from the other treatments also were held.

The $1 \mathrm{~W}, 4 \mathrm{~W}$, and $8 \mathrm{~W}$ bolts were arranged in blocks in the forest, $30-50 \mathrm{~m}$ from the clear-felled area, with ca $10 \mathrm{~m}$ between blocks and $10 \mathrm{~cm}$ between bolts. All bolts were placed on lying wooden poles to avoid ground contact. On the first day of the flight period, on 20 May, Ips typographus attacks were induced with a pheromone bait hung just above each block. As the first attacks were observed, the baits were removed.

On 16 July, each bolt was hung in an emergence trap situated outdoors and in the shade. The trap consisted of a white cotton bag (diameter $40 \mathrm{~cm}$, length $110 \mathrm{~cm}$ ) with a collecting funnel forming the bottom. Emerging insects were collected 1-2 times weekly from 21 July to 3 Nov. During winter the bolts lay unprotected on the ground. On April 10, the bolts were taken inside and put in paper cartons. Insects emerging in glass vials were collected twice weekly from 14 April to 25 May. 
All insects that emerged as adults were determined to species, except Diptera from the genera Medetera spp. and Lonchaea spp. which were sampled to determine dominant species. Larvae were determined to species if possible, otherwise to genus or family (larvae of many species are not described). Mites (Acarida) were not counted or determined. Once emergence had been completed in May the bolts were stored at $-5^{\circ} \mathrm{C}$ until autumn when the bark on each bolt was peeled off and Ips typographus galleries were counted.

\section{Results}

The longer the bolts were exposed the lower was the productivity of Ips typographus (Table 1). This ranking was consistant in each of the 6 blocks. In a two-way analysis of variance, almost all of the variance in productivity was attributable to treatment effects (treatment: $F=66.5, d f=3,15, P<0.001$; block: $F=3.8, d f=5,15, P<0.05)$.

Breeding density of Ips typographus was somewhat higher in the $1 \mathrm{~W}$ treatment than in the other treatments (Table 1). Much of the variance in breeding density was attributable to block effects (treatment: $F=7.2, d f=3,15, P<0.01$; block: $F=19.1, d f=5,15, P<0.001$.

The arthropods that emerged from the bolts are given by number and species (or genus) in Table 2. The later the bolts were caged, the more species were recorded. The total number of arthropods emerging was similar for all treatments, i.e. between 6000 and 6500 . Of the total number of emerging artropods, Ips typographus comprised $99 \%$ in the $0 \mathrm{~W}$ treatment, $87 \%$ in the $1 \mathrm{~W}$ treatment, $44 \%$ in the $4 \mathrm{~W}$ treatment, and only $19 \%$ in the $8 \mathrm{~W}$ treatment. The corresponding figures for predators and parasitoids were $0.2 \%$, $0.2 \%, 6.6 \%$, and $21.5 \%$ respectively.
Parasitic Hymenoptera were found in all treatments but were abundant only in the $8 \mathrm{~W}$ treatment. Lonchaea spp. and Quedius plagiatus occurred exclusively in the $8 \mathrm{~W}$ treatment. Thanasimus spp. occurred in similar numbers in the $4 \mathrm{~W}$ and $8 \mathrm{~W}$ treatments as did Medetera spp. Small staphylinid larve, mostly Phloeonomus spp. were abundant in the $4 \mathrm{~W}$ and $8 \mathrm{~W}$ treatments. In contrast to other insect groups, larvae of Epuraea spp. were most abundant in the $1 \mathrm{~W}$ treatment.

In Table 3 emerging arthropods have been pooled in groups according to their size and feeding habits, and the mean number emerging per unit of bark surface is given by treatment and group. The variance in number of emerged specimens for most groups was moderate, and the pattern of occurrence consistant in all blocks (P. chalcographus, however, was present only in three blocks).

Diptera were sampled throughout their emergence period. Of 67 sampled specimens of Medetera spp., 64 were $M$. signaticornis, 2 were M. excellens, and 1 was M. breviseta. Of 15 Lonchaea spp. all were L. bruggeri.

Emergence patterns of different species and genera reveal differences in phenology and overwintering behaviour (Fig. 1). Less than 10\% of the Ips typographus overwintered under the bark and emerged in spring. In contrast most Diptera overwintered under the bark (Medetera spp. $85 \%$, Lonchaea spp. 97\%). Most of the parasitic Hymenoptera emerged in July and August, but $40 \%$ of the Roptrocerus xylophagorum emerged the following spring. Most predacious and saprophagous Coleoptera emerged in autumn as larvae.

Median emergence for Ips typographus occurred more than one month earlier in the $0 \mathrm{~W}$ treatment than in the other treatments, indicating that the development rate was faster in that treat-

Table 1. Mean $( \pm S D)$ productivity and breeding density of Ips typographus in spruce bolts left uncaged in the forest for $0,1,4$, and 8 weeks $(0 \mathrm{~W}, 1 \mathrm{~W}, 4 \mathrm{~W}, 8 \mathrm{~W})$ after the initial attacks of Ips typographus. Means followed by different letters are different at $5 \%$ probability level (two-way analysis of variance followed by Tukey test).

\begin{tabular}{lcccc}
\hline & OW & $1 \mathrm{~W}$ & $4 \mathrm{~W}$ & $8 \mathrm{~W}$ \\
\hline Productivity (offspring/egg gallery) & $6.7^{a} \pm 1.2$ & $5.3^{b} \pm 0.8$ & $2.9^{c} \pm 1.2$ & $1.1^{d} \pm 0.4$ \\
Breeding density (egg galleries $/ \mathrm{m}^{2}$ ) & $420^{a} \pm 55$ & $496^{b} \pm 78$ & $439^{a} \pm 66$ & $451^{a b} \pm 59$ \\
\hline
\end{tabular}


Table 2. Arthropods emerging from spruce bolts left uncaged in the forest for 0 to 8 weeks $(0 \mathrm{~W}, 1 \mathrm{~W}, 4 \mathrm{~W}, 8 \mathrm{~W})$ after the initial attacks of Ips typographus. Total number for 6 bolts per treatment. Feeding habits have been extracted from literature cited in paragraph 3 of Introduction. Abbreviations: $\mathrm{L}=$ larva, $\mathrm{A}=$ adult, $\mathrm{Do}=$ dominant species, $\mathrm{Pr}=$ present species, parasitoid $\mathrm{L}$, $\mathrm{P}$, or $\mathrm{A}=$ parasitoid of bark beetle larvae, pupae or adult respectively. ${ }^{*}=$ found when peeling bolts, ${ }^{* *}=$ at least two species.

\begin{tabular}{|c|c|c|c|c|c|c|}
\hline & Stage & OW & $1 \mathrm{~W}$ & $4 W$ & $8 W$ & Feeding habit \\
\hline \multicolumn{7}{|l|}{ Insecta } \\
\hline \multicolumn{7}{|l|}{ Coleoptera } \\
\hline \multicolumn{7}{|l|}{ Staphylinidae } \\
\hline \multirow[t]{2}{*}{ Quedius plagiatus (Gyllenhal) } & A & 0 & 0 & 0 & 5 & predator \\
\hline & $\mathrm{L}$ & 0 & 0 & 0 & 15 & predator \\
\hline \multirow[t]{2}{*}{ Nudobius lentus Erichsson } & $A$ & 0 & 0 & 0 & 2 & predator \\
\hline & L & 0 & 0 & 0 & 4 & predator \\
\hline Phloeonomus sjoebergi Strand & A & 1 & 5 & 4 & 18 & unclear \\
\hline Phloeonomus spp. & $\mathrm{L}$ & 14 & 27 & 148 & 290 & unclear \\
\hline Leptusa pulchella (Mannerheim) & A & 0 & 0 & 0 & 2 & unclear \\
\hline Phloeopora testacea Mannerheim & $A$ & 0 & 0 & 1 & 5 & unclear \\
\hline Placusa incompleta Sjöberg & A & 0 & 0 & 0 & 4 & unclear \\
\hline Staphylinidae, unknown genus & $\mathrm{L}$ & 0 & 1 & 63 & 108 & unclear \\
\hline \multicolumn{7}{|l|}{ Histeridae } \\
\hline Plegaderus vulneratus (Panzer) & $A$ & 0 & 0 & 0 & 1 & predator \\
\hline Plegaderus spp. & $\mathrm{L}$ & 0 & 0 & 0 & 2 & predator \\
\hline \multicolumn{7}{|l|}{ Cleridae } \\
\hline Thanasimus spp & L & 0 & 0 & 23 & 25 & predator \\
\hline \multicolumn{7}{|l|}{ Nitidulidae } \\
\hline Epuraea thoracica Tournier & $A$ & 1 & 0 & 0 & 1 & unclear \\
\hline E. pygmaea (Gyllenhal) & A & 0 & 0 & 2 & 1 & unclear \\
\hline Epuraea spp. & $\mathrm{L}$ & 26 & 786 & 39 & 99 & unclear \\
\hline \multicolumn{7}{|l|}{ Rhizophagidae } \\
\hline \multirow{2}{*}{ Rhizophagus dispar (Paykull) } & A & 0 & 0 & 0 & 2 & scavenger \\
\hline & $\mathrm{L}$ & 0 & 0 & 0 & 9 & scavenger \\
\hline R. ferrugineus (Paykull) & $\bar{A}$ & 0 & 1 & 0 & 10 & predator \\
\hline \multicolumn{7}{|l|}{ Cerambycidae } \\
\hline Rhagium inquisitor (L.)* & $L$ & 0 & 0 & 0 & 39 & phloem-feeding \\
\hline \multicolumn{7}{|l|}{ Scolytidae } \\
\hline Ips typographus (L.) & A & 6422 & 5640 & 2846 & 1129 & phloem-feeding \\
\hline Pityogenes chalcographus (L.) & $A$ & 2 & 6 & 475 & 313 & phloem-feeding \\
\hline Dryocoetes autographus (L.) & A & 0 & 0 & 10 & 63 & phloem-feeding \\
\hline Crypturgus spp.** ${ }^{* *}$ & A & 0 & 0 & 2205 & 2481 & phloem-feeding \\
\hline \multicolumn{7}{|l|}{ Hymenoptera } \\
\hline \multicolumn{7}{|l|}{ Pteromalidae } \\
\hline Roptrocerus brevicornis Thomson & $A$ & 0 & 0 & 14 & 90 & parasitoid LP \\
\hline R. xylophagorum Ratzeburg & $A$ & 0 & 2 & 35 & 280 & parasitoid L P \\
\hline Rhopalicus tutele Walker & A & 0 & 1 & 2 & 466 & parasitoid LP \\
\hline Dinotiscus eupterus Walker & A & 0 & 0 & 0 & 23 & parasitoid LP \\
\hline Tomicobia seitneri Ruschka & A & 13 & 3 & 6 & 6 & parasitoid $\mathrm{A}$ \\
\hline Karpinskiella pityophtori Boucek & $A$ & 0 & 1 & 3 & 4 & parasitoid $A$ \\
\hline \multicolumn{7}{|l|}{ Braconidae } \\
\hline Rhopalophorus clavicornis Wesmael & $A$ & 0 & 0 & 0 & 3 & parasitoid $\mathrm{A}$ \\
\hline Cosmophorus regius Nietzabitowski & A & 0 & 0 & 0 & 1 & parasitoid $\mathrm{A}$ \\
\hline Diptera & & & & & & \\
\hline Dolichopodidae & & & & & & \\
\hline Medetera signaticornis Loew & $A$ & 0 & 1 & Do & Do & predator \\
\hline M. excellens Frey & $A$ & 0 & 0 & $\mathrm{Pr}$ & $\mathrm{Pr}$ & predator \\
\hline M. breviseta Parent & A & 0 & 0 & $\operatorname{Pr}$ & $\mathrm{Pr}$ & predator \\
\hline Medetera spp. (total) & $A$ & 0 & 1 & 331 & 356 & predator \\
\hline Lonchaeidae & & & & & & \\
\hline Lonchaea bruggeri Morge & A & 0 & 0 & 0 & Do & unclear \\
\hline Lonchaea spp. (total) & A & 0 & 0 & 0 & 132 & unclear \\
\hline Stratiomyidae & & & & & & \\
\hline Zabrachia minutissima Zetterstedt & $A$ & 0 & 0 & 0 & 10 & scavenger \\
\hline Arachnoidea & & & & & & \\
\hline Pseudoscorpionida & & & & & & \\
\hline Chernes cimicoides (F.) & $A$ & 0 & 0 & 0 & 2 & predator \\
\hline & $L$ & 0 & 0 & 0 & 6 & predator \\
\hline Total artropodods (excl. Acarida) & & 6479 & 6474 & 6207 & 6007 & \\
\hline Total species (minimum) & & 5 & 11 & 18 & 32 & \\
\hline
\end{tabular}


ment, probably due to higher temperature during storage in the greenhouse. The emergence patterns of Ips typographus were similar for the $1 \mathrm{~W}$, $4 \mathrm{~W}$, and $8 \mathrm{~W}$ treatments (median emergence date 13-17 September).

\section{Discussion}

The exclusion of insect associates led to a 6-fold increase in Ips typographus productivity (Table $1,0 \mathrm{~W}$ vs $8 \mathrm{~W}$ ). In other words, the natural enemies reduced bark beetle productivity by $83 \%$. The same relative difference was reached in bark beetle emergence (Table 3 ). This difference, as well as the density of predators and parasitoids are in agreement with the results of Linit \& Stephen (1983) for Dendroctonus frontalis Zimmerman (82\% reduction, 366 predators and 336 parasitoids per $\mathrm{m}^{2}$, cf Table 3 ) In other studies with similar densities of predators in the exposure treatment, but with virtually no parasitoids, the differences between exclusion and exposure treatments was 30-40\% (Miller 1986, Riley \& Goyer 1986).
Obviously natural enemies was the main cause for the large differences in bark beetle productivity between treatments. Other factors that could have affected differences in productivity are the higher breeding density in the $1 \mathrm{~W}$ treatment and the faster development in the 0W treatment. It is unclear what effect, if any, developmental rate had on productivity in this case. There is an inverse relationship between breeding density and productivity (see e.g. Thalenhorst 1958). Productivity drops as breeding density increases and levels off at high densities. In this study productivity should not have been too sensitive to variations in breeding density since density was high in all bolts.

The difference in productivity between the OW and $1 \mathrm{~W}$ treatments was rather small but consistant in all blocks. Besides differences in developmental rate and breeding density (see above), there was a large difference in the number of emerging Epuraea larvae between these two treatments (see Tables 2 and 3). Field observations by Nuorteva (1956) indicate that adults of $E$. pygmaea can feed on Ips typographus eggs. The feeding habits of Epuraea larvae are not clear.

Table 3. Number of insects emerging per $\mathrm{m}^{2}$ of bark surface from spruce bolts left ungaged in the forest for 0 to 8 weeks (0W, 1W, 4W, 8W) after the initial attacks of Ips typographus. Means of 6 replicates $\pm 95 \%$ confidence intervals.

\begin{tabular}{|c|c|c|c|c|}
\hline Group of insects & oW & $1 \mathrm{~W}$ & $4 W$ & $8 W$ \\
\hline Ips typographus & $3072 \pm 461$ & $2868 \pm 450$ & $1402 \pm 560$ & $543 \pm 229$ \\
\hline $\begin{array}{l}\text { Large predators }(>10 \mathrm{~mm}) \\
\quad(\text { Thanasimus, Quedius, Nudobius) }\end{array}$ & 0 & 0 & $11 \pm 9$ & $23 \pm 11$ \\
\hline $\begin{array}{l}\text { Small predators } \\
\text { Medetera } \\
\text { Rhizophagus, Plegaderus, Chernes }\end{array}$ & $\begin{array}{l}0 \\
0\end{array}$ & $\begin{array}{l}0 \\
0\end{array}$ & $\begin{array}{l}155 \pm 56 \\
0\end{array}$ & $\begin{array}{c}166 \pm 52 \\
8 \pm 8\end{array}$ \\
\hline $\begin{array}{l}\text { Unclear feeding habits } \\
\text { small Staphylinidae } \\
\text { Epuraea } \\
\text { Lonchaea }\end{array}$ & $\begin{array}{c}7 \pm 8 \\
13 \pm 21 \\
0\end{array}$ & $\begin{array}{c}14 \pm 8 \\
412 \pm 237 \\
0\end{array}$ & $\begin{array}{c}104 \pm 65 \\
20 \pm 15 \\
0\end{array}$ & $\begin{array}{c}198 \pm 112 \\
46 \pm 24 \\
64 \pm 29\end{array}$ \\
\hline Parasitoids of $I p s$ & $6 \pm 9$ & $3 \pm 3$ & $28 \pm 35$ & $445 \pm 130$ \\
\hline Competitors to Ips & & & & \\
\hline $\begin{array}{l}\text { Rhagium } \\
\text { Dryocoetes }\end{array}$ & $\begin{array}{l}0 \\
0\end{array}$ & $\begin{array}{l}0 \\
0\end{array}$ & $\begin{array}{c}0 \\
2 \pm 5\end{array}$ & $\begin{array}{l}19 \pm 10 \\
32 \pm 19\end{array}$ \\
\hline Pityogenes & $1 \pm 3$ & $3 \pm 7$ & $241 \pm 474$ & $174 \pm 265$ \\
\hline
\end{tabular}



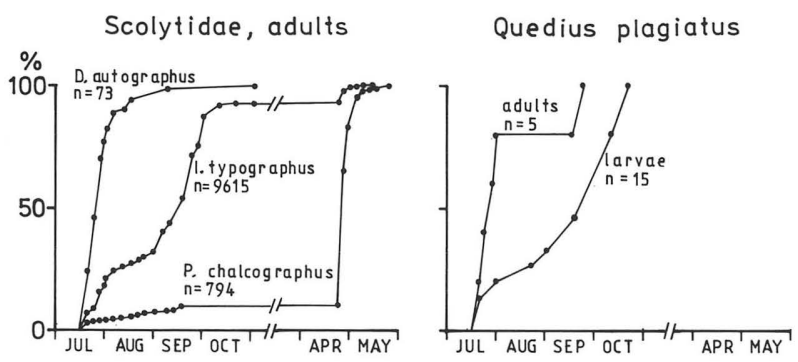

Phloeonomus spp.
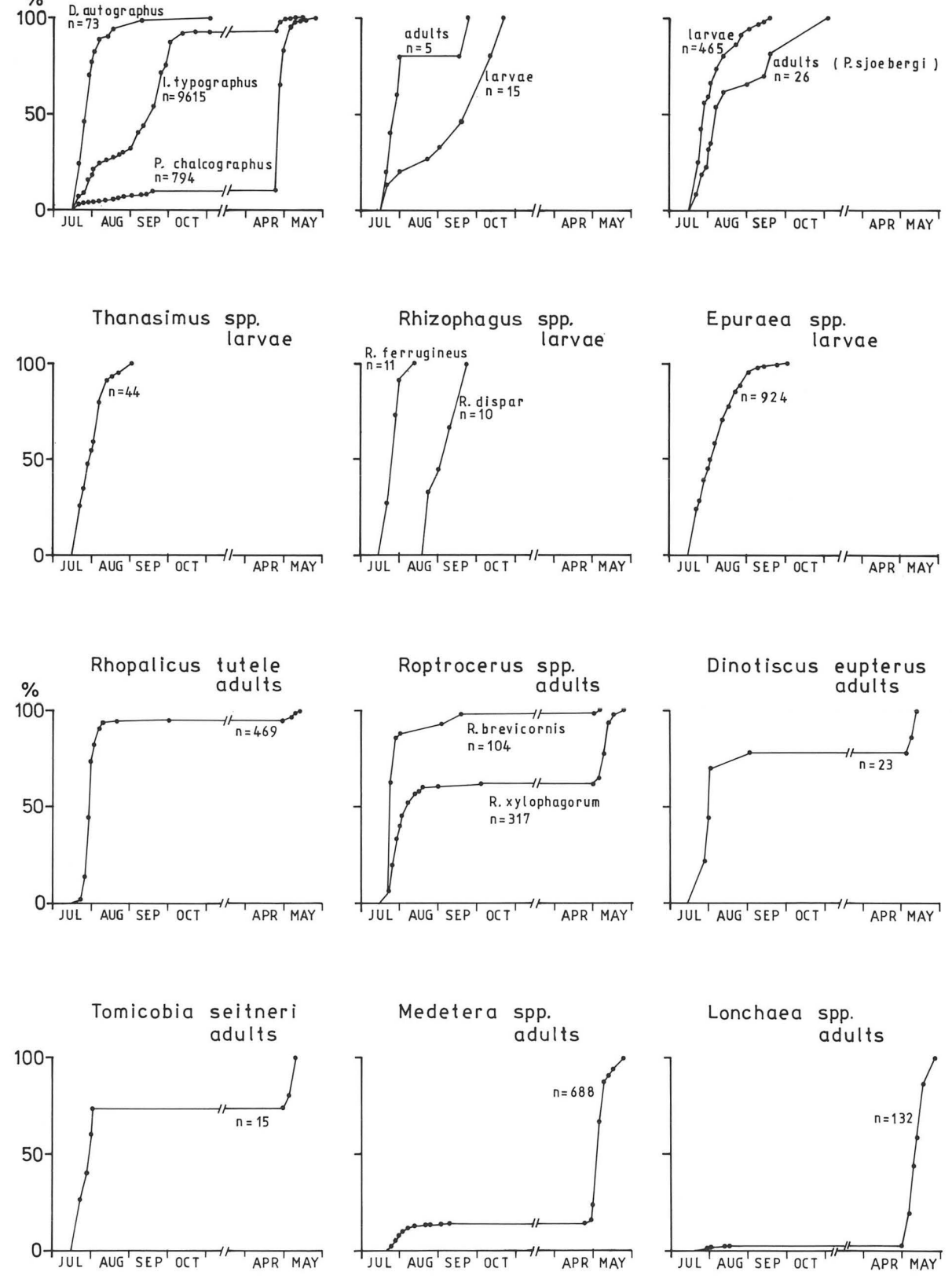

Fig. 1. Emergence patterns of insects emerging from spruce bolts attacked in the forest by lps typographus mainly on 20 and 21 May 1986 (1W, 4W, and 8W treatments). 
Observations by Hanson (1937) and Nuorteva (1956) indicate that they can feed on bark beetle brood, whereas Mamaev et al. (1977) considers them not to be entomophagous.

The difference in productivity between $1 \mathrm{~W}$ and $4 \mathrm{~W}$ treatments was obviously caused by predators. The predators involved were Medetera spp. and Thanasimus spp., of which M. signaticornis occurred at high densities and was most important.

The large difference in productivity between $4 \mathrm{~W}$ and $8 \mathrm{~W}$ treatments can be attributed mainly to the activity of parasitic Hymenoptera, of which Rhopalicus tutele and Roptrocerus xylophagorum were most abundant. Predation by Lonchaea bruggeri and Quedius plagiatus as well as other occasional predators, e.g. Plegaderus vulneratus, Chernes cimicoides and possibly also small Staphylinidae (see below) could have contributed to the observed difference between these treatments.

The fact that the density of Epuraea larvae in the $4 \mathrm{~W}$ and $8 \mathrm{~W}$ treatments was lower than in the $1 \mathrm{~W}$ treatment might be explained by treatmentrelated differences in predator numbers (see Table 3). Epuraea larvae were probably eaten by predators.

Larvae of small Staphylinidae e.g. Phloeonomus spp. were abundant in the $4 \mathrm{~W}$ and $8 \mathrm{~W}$ treatments. Most of the unidentified staphylinid larvae (see Table 2) were probably Placusa spp. and Phloeopora spp., but I was unable to identify them with certainty. The feeding habits of these small larvae are unclear. They seem to be too small to attack large Ips typographus larvae, and in this study most of them arrived too late to attack eggs. Gut content analysis indicated that larvae of Placusa despecta Erichson were mycetophagous (Ashe 1990). Field observations indicate that adults of Phloeopora testacea (Klausnitzer \& Förster 1974, Nuorteva 1956), Phloeonomus pusillus Gravenhorst (Langor 1991), and Placusa tachyporoides Waltl $(=P$. infima, Escherich 1923:49, citing Fleischer) can eat bark beetle eggs or larvae.

Rhizophagus larvae occurred in low numbers. Of the two species emerging, $R$. ferrugineus and $R$. dispar, the latter seems to be mainly saprophagous (Merlin et al. 1986). There was a clear difference in emergence patterns between the two species (Fig. 1). The emergence patterns of some species e.g. R. ferrugineus, Epuraea spp., Thanasimus spp., and Tomicobia seitneri show that emergence was intensive directly after the bolts were hung in the emergence bags. This indicates that emergence had started before this date. Thus the density of these species might have been underestimated.

Crypturgus spp. (at least two species) occurred in rather high numbers in the $4 \mathrm{~W}$ and $8 \mathrm{~W}$ treatments. These minute bark beetles do not compete with Ips typographus for food and space, and are probably not important prey for the predators and parasitoids in this study. The other 2 bark beetles Pityogenes chalcographus and Dryocoetes autographus and the cerambycid Rhagium inquisitor are potential competitors, but occurred in rather low numbers and probably they did not affect Ips typographus productivity much $(R$. inquisitor has a two-year life cycle and the larvae were still quite small when the bolts were peeled). Most of the predators and parasitoids found here can attack $P$. chalcographus and $D$. autographus. The abundance and relatively large size of most of the $R h$. tutele and $R$. xylophagorum specimens that emerged suggest that they had fed on Ips typographus. Most $R$. brevicornis specimens were small (1-2 mm) suggesting that $P$. chalcographus was the main host. Karpinskiella pityophtori is considered to be a parasitoid of Pityogenes spp. (Hedqvist 1963).

Most of the predatory and saprophagous Coleoptera emerged as larvae in authumn. Forsslund (1941) reported that Thanasimus larvae overwintered mainly outside trees killed by Ips typographus in central and northern Sweden. Apparently this behaviour is common for several species, and it could be an adaption to the climate in the nordic region, where winters often are cold and larvae might not survive above the snow.

The sequence of arrival of the bark beetle enemies agrees with results of Stephen \& Dahlsten (1976) from Dendroctonus brevicomis LeConte. In that study the arrival of the parasitic Hymenoptera, especially $R$. xylophagorum, was well synchronized with the development of the host; i.e. most arrived when the host was in the last larval instar or pupal stage. Other observations indicate that $R$. xylophagorum (Berisford et 
al. 1971) and Rh. tutele (Krüger \& Mills 1990), the two dominant parasitoids in the present study, mainly attack those stages. Tomicobia seitneri attacks Ips typographus adults outside the tree. Thus the specimens of $T$. seitneri in the $0 \mathrm{~W}$ treatment probably emerged from beetles that had been attacked before they were released in the cages.

The fact that Ips typographus and some of its natural enemies differed in their arrival and emergence patterns has practical implications. Forestry practices should be carried out in ways that minimize adverse impacts on bark beetle enemies. For example, bark beetle attacked timber should be removed from the forest before the peak arrival of the parasitoids, i.e. when bark beetle brood are in their late larval or pupal stages (around 1 July for Ips typographus in central Sweden). Present regulations in Sweden prescribe removal of Ips typographus attacked timber before 1 August, when bark beetle emergence usually starts. Furthermore, removal of colonized trees and timber after the autumn emergence of Ips typographus should be avoided. Most Ips typographus have emerged by 1 October, but predatory Diptera and parasitic Hymenoptera still remain and emerge the following spring.

The study demonstrates that bark beetle enemies in the nordic region, where most bark beetles have only one generation per year, can reach high enough densities to reduce bark beetle emegence to very low levels. The most important factors that influence the population density of these entomophages have yet to be identified. Forestry practices. e. g. clear-felling, thinning, removal of windthrown stems etc., strongly influence the distribution and abundance of bark beetles in time and space. However the numerical responses (reproductive and migratory) of bark beetle enemies to changes in prey density are poorly understood. Better knowledge in this topic may be essential to effectively integrate control of destructive bark beetles with management of forests.

Acknowledgments. The following persons are gratefully acknowledged: Bengt Ehnström and Bert Wiklund for help in identifying Coleoptera, Karl-Johan Hedqvist for help in identifying Hymenoptera, Heino Õunap for help in identifying Diptera, Stanislav Snäll for identifying
Pseudscorpionida, Roy Danielsson for the loan of the T. Palm collection of Coleoptera larvae at Lund University, Hubertus H. Eidmann for comments on the manuscript, Rune Axelsson for drawing figure, and David Tilles for correcting the English. The study was mainly financed by grants from the Swedish National Board of Forestry and the Swedish Environmental Protection Agency.

\section{References}

Ashe, J. S. 1990: The larvae of Placusa Mannerheim (Coleoptera: Staphylinidae) with notes on their feeding habits. - Entomol. Scand. 21:477--485.

Berisford, C. W., Kulman, H. M., \& Pienowski, R. L. 1970: Notes on the biologies of hymenopterous parasites of Ips spp. bark beetles in Virginia. - Can. Entomol. 102:484-490.

Dahlsten, D. L. 1981: Relationships between bark beetles and their natural enemies. - In: Mitton, J. B. \& Sturgeon, K. B. (eds.), Bark beetles in North American conifers: 140-182. University of Texas press, Austin.

Esherich, K. 1923: Die Forstinsekten Mitteleuropas. 2. Berlin. 663 pp.

Forsslund, K.-E. 1941: Till kännedom om myrbaggens (Clerus formicarius) biologi. - Sveriges Skogvårdsförenings Tidskrift 7:95-98.

Hanson, H. S. 1937: Notes on the ecology and control of pine beetles in Great Britain. - Bull. Entomol. Res. 28:185-242.

Hedqvist, K.-J. 1963: Die Feinde der Borkenkäfer in Schweden. 1. Erzwespen (Chalcidoidea). — Studia Forest. Suecica 11: 1-176.

Klausnitzer, B. \& Förster, G. 1974: Zur Kenntnis der Parasiten und Episten des Buchdruckers Ips typographus L. (Col., Scolytidae). — Entomol. Ber. 1974:1-42.

Krüger, K. \& Mills, N. J. 1990: Observations on the biology of three parasitoids of the spruce bark beetle, Ips typographus (Col., Scolytidae): Coeloides bostrychorum, Dendrosoter middendorffii (Hym., Braconidae) and Rhopalicus tutela (Hym., Pteromalidae). - J. Appl. Entomol. 110:281-291.

Langor, D. W. 1991: Arthropods and nematodes co-occurring with the eastern larch beetle Dendroctonus simplex (Col.: Scolytidae), in Newfoundland. Entomophaga 36:303-313.

Linit, M. J. \& Stephen, F. M. 1983: Parasite and predator component of within-tree southern pine beetle mortality (Coleoptera, Scolytidae) mortality. - Can. Entomol. 115:679-688.

Mamaev, B. M., Krivoscheina, N. P. Pototskaya, V. A. (Мамаев, Б. М., Кривошеина, Н. П. Потоцкая, В. A.) 1977: [Identification of larvae — predatory insects - entomophages of stem borers.] (in Russian) "Nauka", Moscow. 392 pp.

Merlin, J., Parmentier, C., \& Gregoire, J. C. 1986: The feeding habits of Rhizophagus dispar, an associate of 
bark beetles. - Med. Fac. Landbouw. Rijksuniv. Gent 51/3a:915-923.

Miller, M. C. 1984: Effects of exclusion of insect associates on Ips calligraphus (Germ.) (Coleoptera, Scolytidae) brood emergence. - Zeitschr. Ang. Entomol. 97:298-304.

- 1986: Survival of within-tree Ips calligraphus (Col.: Scolytidae): Effect of insect associates. - Entomophaga 31:305-328.

Mills, N. J. 1986: The natural enemies of scolytids infesting conifer bark i Europe in relation to the biological control of Dendroctonus spp. in Canada. - Biocontrol News Inf. 4:305-328.

Moeck, H. A. \& Safranyik, L. 1984: Assessment of predator and parasitoid control of bark beetles. - Can. For. Serv. Inf. Rep. B.C.-X-248, Pacific Forest Research Centre. 23 pp.

Moore, G. E. 1972: Southern pine beetle mortality in North Carolina caused by parasites and predators. - Environ. Entomol. 1:58-65.

Moser, J. C. \& Bogenschütz, H. 1984: A key to the mites associated with flying Ips typographus in South Germany. - Zeitschr. Ang. Entomol. 97:437-450.

Moser, J. C., Eidmann, H. H., Regnander, J. 1989: The mites associated with Ips typographus in Sweden. Ann. Entomol. Fennici 55:23-37.

Nuorteva, M. 1956: Über den Fichtenstamm-Bastkäfer, Hylurgops palliatus und seine Insektenfeinde. - Acta Entomol. Fennica 34:56-65.

- 1957: Zur Kenntniss der parasitischen Hymenopteren der Borkenkäfer Finnlands. - Ann. Entomol. Fennici 23:47-71

- 1959: Untersuchungen über einige in den Frassbildern der Borkenkäfer lebende Medetera-Arten (Dipt., Dolichopodidae). - Ann. Entomol. Fennici 25:192-210.
Ounap, H. 1980: On the specific composition of the predatory Coleoptera established in boreholes of bark beetles inhabiting conifers. (in Russian with English summary) - Metsanduslikud Uurimused 26:34-43.

- 1986: The species composition of Hymenoptera as parasites of bark beetles inhabiting conifers in Estonia. (in Russian with English summary) - Metsanduslikud Uurimused 32:79-88.

Pettersen, H. \& Tvermyr, S. 1971: Granbarkborrens naturlige fiender. - Skogeieren 12/1971:24-25.

Riley, M. A. \& Goyer, R. A. 1986: Impact of beneficial insects on Ips spp. (Coleoptera, Scolytidae) bark beetles in felled loblolly and slash pines in Louisiana. Environ. Entomol. 15:1220-1224.

Saalas, U. 1917: Die Fichtenkäfer Finnlands. 1. - Ann. Acad. Sci. Fennicae Ser. A, 8. 547 pp.

Sachtleben, H. 1952: Die parasitischen Hymenoptera des Fichtenborkenkäfers Ips typographus L. - Beitr. Entomol. 2:10-189.

Stephen, F. M. \& Dahlsten, D. L. 1976: The arrival sequence of the arthropod complex following attack by Dendroctonus brevicomis (Coleoptera: Scolytidae) in ponderosa pine. - Can. Entomol. 108:283-304.

Thalenhorst, W. 1958: Grunzüge der Populationsdynamik des grossen Fichtenborkenkäfers Ips typographus L. - Schriftenr. Forstl. Fak. Univ. Göttingen Bd. 21. 126.

Weslien, J. \& Regnander, J. 1992: The influence of natural enemies on brood production in Ips typographus (Coleoptera, Scolytidae) with special reference to egglaying and predation by Thanasimus formicarius (L.) (Coleoptera, Cleridae). - Entomophaga 37:333-342.

Received 11.XII.1991 